\title{
Comparative study of Profitability and Liquidity analysis of Islamic Banks in Bangladesh
}

\section{Nazneen Fatema \& Abdullah Mohammed Ibrahim}

Lecturer in Finance, International Islamic University Chittagong, Dhaka, Bangladesh Assistant Professor of Marketing, Northern University Bangladesh, Dhaka, Bangladesh

\begin{abstract}
In this depressed world financial scenario, Islamic banking has emerged as a strong alternate financial system. Its growth is not restricted to the Muslim societies but Islamic financial products are also gaining popularity among non-Muslim countries. The objective of this paper is to scrutinize and compare the liquidity and profitability performances of five Islamic banks in Bangladesh in between the period 2005 and 2011. In order to scan the performances, this study highlights on different standards of liquidity and profitability measurements logical to Islamic philosophy; such as liquidity and profitability ratios, liquidity reserves by the banks, net liquidity gap, profit creation from different sectors of the banks, etc. Multiple correlations among liquidity and profitability ratios are shown here. The results of all these measurements are quite apparent. In particular, among all the independent variables, at 90\% confidence level only investment to total assets is found to be significantly affecting Return on Assets (a measurement of profitability ratio) for Islami Bank Bangladesh Ltd., Shahjalal Islami Bank Ltd. and EXIM Bank Ltd., whereas with Return on Equity for only Shahjalal Islami Bank Ltd. However, multicollinearity has been found to be a great issue when considering liquidity impact on profitability for Islami Bank Bangladesh Ltd., EXIM Bank Ltd. and Social Islami Bank Ltd. Overall P-values suggest that at 95\% confidence level liquidity model proves significant on ROA for Islami Bank Bangladesh Ltd. and Social Islami Bank Ltd., while on ROE for Islami Bank Bangladesh Ltd. and Shahjalal Islami Bank Ltd.
\end{abstract}

Key word: Islamic banking system, Profitability analysis, Liquidity analysis

JEL Classification Code: G21; G30; M20

\section{INTRODUCTION}

Islamic banking system has been expanding so rapidly over the past few years. In addition, it has been developing significantly around the world including Middle Eastern countries, Southeast Asian countries, European countries and even in North American countries. It is 
surprising to note that global conventional banks like HSBS, Standard Chartered Bank, Deutsche Bank, Citibank, etc, have also set up separate Windows/Divisions to structure Islamic financial products and are offering Islamic banking services to their Muslim clients and even to those non-Muslim clients who are interested in profit and loss sharing (PLS) financial instruments (Awan, 2009). The actual role of Islamic bank inherits in promoting and empowering the banking services and product based on Islamic principles. The main principles of Islamic banking comprise of prohibition of interest in all forms of transactions, and undertaking business and trade activities on the basis of fair and legitimate profit (Haron and Shanmugan, 1997). But according to Islamic principles, reward, i.e. profit without sharing the risks or hazards in the economic understandings is totally prohibited. Perhaps, the most significant risk of an Islamic bank is to build a sound liquidity management. So, what should be the crucial choice of an Islamic bank; whether to take fundamental choice of profit maximization or to concern more on assurance of liquidity in any banking business under Islamic principles? Possibly the answer could rise when we examine the real world scenario; i.e. real Islamic banks and their performance to see how they perform to manage noise liquidity in accordance with maintaining handsome profitability.

The objective of this study is to enlighten on the comparative liquidity and profitability performance of Islamic banks and to measure the weight of significance of Islamic banks' liquidity on profitability. This study considers five (5) among seven (7) Islamic banks currently incorporating in Bangladesh along with their seven year's data. From that ground the study is rational to meet the need of different users.

\section{LITERATURE REVIEW}

Islamic Banking System is defined as those banks that claim to follow Shari'a (Islamic law) in their business transactions, Shari'a requires these transactions to be in lawful (Halal) form and prohibits transactions that involving interest (Riba) (Maali, Casson, and Napier, 2006). The core concept of Islamic banking is to provide services to its customers free from interest and the giving and taking of interest (riba) is prohibited in all transactions (Lewis and Algaoud, 2001). Prohibition of interest (riba) makes Islamic banking system differ from conventional banking system. In other words, the main difference between Islamic and conventional banks is the use of money. In conventional banks, money is used as a commodity that is bought and sold through the interest's usage according to Alkassim (2005).

Rejection of interest's usage raises the question of the alternatives of interest mechanism adopted in Islamic system. If dealing with interest rate is prohibited, how Islamic banking works? Here Profit-Loss Sharing System (PLS) takes the place as a method of resource allocation; it will be explained deeply in the following section. Beside the absence of interest in all financial transactions, there are religious rules or principles should each Islamic financial institution applies in investment behavior to achieve Islamic norms. There are four main areas where the Islamic banks find it difficult to finance under profit-loss sharing (PLS) scheme: a) participating in long-term low yield projects, b) financing the small businessman, c) granting non-participating loans to running businesses and, d) financing government borrowing (Ali and Howlader, 2005).

A study by Haron (2004) found that liquidity, total expenditures, funds invested in Islamic securities, and the percentage of the profit-sharing ratio between the bank and the borrower of funds are highly correlated with the level of total income received by the Islamic banks. Similar effects are also found for external factors such as interest rates, market share and size of the banks. Other determinants such as funds deposited into current accounts, total capital 
and reserves, the percentage of profit sharing between bank and depositors, and money supply also play a major role in influencing the profitability of Islamic banks.

While making significant progress in return on assets (ROA) and return on equity (ROE), the liquidity performance of Bank Islam Malaysia (BIMB, the single full-fledged Islamic bank in Malaysia) between 1984-89 and 1990-97 in various measures such as cash deposit ratio, loandeposit ratio and current ratio showed neither deterioration nor improvement (Samad and Hassan, 1999). Chowdhury and Ahmed (2009) investigated that total deposits of Islamic Bank Bangladesh Ltd. was higher in comparison to some non-Islamic banks during 2002 to 2006 period. Saifullah (2010) argued that Islamic banks in Bangladesh are superior to Conventional banks after an overall assessment of financial performance including liquidity and profitability position.

Sudin Haron (1996), while discussing external determinants of the profitability of Islamic Banks, argued that conventional banking theory postulates that the bigger the market, the more profit the banks earn, this theory is not necessarily true for Islamic banks. Islamic banks perform well due to efficient use of capital in short-term financing. Similarly, Islamic banks in a competitive market are better managed than those in the monopolistic markets. This finding is also in line with general assumption. Those businesses which operate in a competitive environment must be alert to the changes and produce innovative strategies and policies, if they wish to remain in the market. In contrast, conventional banks perform better in monopolistic environment as competitive environment involve them in moral hazard and adverse selection, causing high rate of default and less profitability.

Bashir and Hassan (2004) research study is a comprehensive piece of literature covering every aspect of examining profitability of Islamic banks. Similar to Bashir (2000), Bashir and Hassan (2004) studied the determinants of Islamic baking profitability between 1994 and 2001 for 21 countries. Their findings show that Islamic banks have a better capital asset ratio as compared to commercial banks which means that Islamic banks are well capitalized. Also, their paper used internal and external banks characteristics to determine profitability as well as economic measures, financial structure variables, and country variables. Bashir and Hassan also found total assets to have a negative relationship with profitability which amazingly means that smaller banks are more profitable. In addition, during an economic boom, banks profitability seems to improve because there are fewer non-performing loans. Inflation, on the other hand, does not have any effect on Islamic bank profitability. The results also indicate that overhead expenses for Islamic banks have a positive relation with profitability which means if expenses increase; profitability also increases.

The essence of liquidity management problem arises from the fact that there is a trade-off between liquidity and profitability and mismatch between demand and supply (Khan and Ahmed, 2001). While the bank has no control over the sources of fund (deposits), it can control the use of funds. Most banks now keep protective reserves on top of planned reserves. Excess liquidity is reported in nearly all Islamic banks (Ali and Howlader, 2005). Due to unavailability of local capital market, Islamic banking sectors have been suffering from investing idle fund in liquid venture (Rashid and Nishat, 2009). Surplus liquidity with Islamic banks cannot be easily transferred to conventional banks since the Islamic banks do not accept interest; however there is room for exchange of surplus funds among the Islamic banks on a Mudarabah / Musharakah basis. The greater the number of Islamic banks and wider their activities, the greater will be the scope of cooperation in this field. When making comparisons across firms (or over time), it is useful to control for differences in their resource base (Foster, 2002). At the same time liquidity of those resources/ assets is of paramount significance for banks (Maheshwari and Maheshwari, 
2002). Akhtar, Ali and Sadaqat (2011) found positive but insignificant relationship of size of the bank and net-working capital to net assets with liquidity risk in Islamic banks. In addition return on assets (ROE) in Islamic banks is found to be positive and significant with liquidity risk at $10 \%$ significance level. While there are lots of works being done on performance comparison between Islamic banks and Conventional banks, to the best of my knowledge, not many works have yet focused on performance evaluation among Islamic banks in Bangladesh in particular. Therefore, the current study emphasizes on liquidity and profitability performance evaluation of Islamic banks in Bangladesh and leaves lots of rooms for upcoming researchers to improve and enrich the current issue in future.

\section{Measures of Variables}

The banks are compared in this study based on multiple liquidity and profitability variables. Banks' liquidity position is compared through examining the liquidity reserves kept by the banks, performance of liquidity ratios and the results of net liquidity gap. Profitability of banks is compared through scanning the ability of creating profits from different sectors, as well as through performance of profitability ratios. Coefficient of variation (CV) is defined as the ratio of the standard deviation to the mean. To compare the influence of Islamic bank's liquidity on profitability using multiple regression analysis, variables were assigned into two sections :

\section{Dependent Variables (Profitability Ratios)}

- $\quad$ Return on Assets $($ ROA $)=$ Net Income after Taxes/ Total Assets

- $\quad$ Return on Equity (ROE) = Net Income after Taxes/ Total Equity Capital Account Independent Variables (Liquidity Ratios)

- $\quad$ Cash \& Due from Banks to Total Assets = Cash \& Due from Banks / Total Assets

- $\quad$ Cash \& Due from Banks to Deposits = Cash \& Due from Banks/ Total Deposits

- Investment (Loans \& Advances) to Total Assets = Investment/ Total Assets

- Investment (Loans \& Advances) to Deposits = Investment/ Total Deposits

To do the analysis following two hypotheses were designed:

- There is an insignificant relationship between liquidity and profitability; (null hypothesis)

- There is a significant relationship between liquidity and profitability; (alternative hypothesis)

\section{Data Collection \& Sample Design}

Among 7 (seven) Islamic banks in Bangladesh, 5 (five) largest Islamic banks have been selected for conducting this research ${ }^{1}$. This study basically depends on the secondary data. The data used here are compiled from bank's each year annual report during 2005 to 2011. The selected banks for this study include the following:

\begin{tabular}{|c|l|l|}
\hline \multicolumn{3}{|c|}{ Table : List of Selected Banks } \\
\hline No. & \multicolumn{1}{|c|}{ Name of the Selected banks } & \multicolumn{1}{|c|}{ DSE Trading Code .* $^{* *}$} \\
\hline 1. & Islami Bank Bangladesh Limited & ISLAMIBANK \\
\hline 2. & Shahjalal Islami Bank Limited & SHAHJABANK \\
\hline 3. & Al-Arafah Islami Bank Limited & ALARABANK \\
\hline 4. & EXIM Bank Limited & EXIMBANK \\
\hline 5. & Social Islami Bank Limited & SIBL \\
\hline
\end{tabular}

${ }^{1}$ Other two Islamic banks have been excluded from this study as because their history is not that long as the selected banks. 
**Throughout this study the banks' names are presented according to their Dhaka Stock Exchange (DSE) Trading Code.

\section{Data Analysis}

Different financial and statistical tools and techniques, namely average, standard deviation, coefficient of variation, Pearson's correlation coefficients (correlation matrix), multiple regressions etc. have been used here to analyze the collected data and make the comparison. In addition descriptive analyses of all statistical findings are also included in this study.

\section{FINDINGS AND ANALYSIS}

\section{Liquidity Performance Analysis of Islamic BankS}

Simply stating, liquidity is the ability to meet any instant need in the form of cash or cash equivalent by selling assets; as we know cash is the most liquid asset by its nature. For bank, liquidity is the ability to meet its financial obligations as they come due. It illustrates that a bank must keep a sufficient amount in reserves to cover any unavoidable circumstance of economy. Islamic bank is not an exception in this regard.

\subsection{Liquidity Maintenance Requirement of Islamic Banks in Bangladesh}

Each Islamic Bank is required to maintain a minimum amount of their total time and demand deposits with Bangladesh (Central) Bank in two different categories, such as, Cash Reserve Requirement (CRR) and Statutory Liquidity Requirement (SLR) ${ }^{2}$. Below, we will see how these requirements were met by all five selected Islamic banks.

\begin{tabular}{|c|c|c|c|c|c|c|}
\hline \multicolumn{7}{|c|}{ Table 1.1: Year-wise CRR maintenance by Islamic Banks (2005-2011) } \\
\hline \multirow[b]{2}{*}{ Year } & \multicolumn{5}{|c|}{ Actual Reserve (\%) } & \multirow{2}{*}{$\begin{array}{c}\text { Required } \\
\text { Reserve (\%) }\end{array}$} \\
\hline & $\begin{array}{c}\text { ISLAMI } \\
\text { BANK }\end{array}$ & $\begin{array}{c}\text { SHAHJA } \\
\text { BANK }\end{array}$ & $\begin{array}{l}\text { ALARA } \\
\text { BANK }\end{array}$ & $\begin{array}{r}\text { EXIM } \\
\text { BANK } \\
\end{array}$ & SIBL & \\
\hline 2005 & $14.65 \%$ & $5.94 \%$ & $6.03 \%$ & $9.51 \%$ & $6.30 \%$ & \multirow{5}{*}{$5.00 \%$} \\
\hline 2006 & $16.13 \%$ & $5.36 \%$ & $6.00 \%$ & $5.91 \%$ & $6.57 \%$ & \\
\hline 2007 & $6.17 \%$ & $5.54 \%$ & $6.56 \%$ & $7.72 \%$ & $7.05 \%$ & \\
\hline 2008 & $10.67 \%$ & $6.09 \%$ & $6.14 \%$ & $7.19 \%$ & $6.80 \%$ & \\
\hline 2009 & $13.23 \%$ & $5.53 \%$ & $8.27 \%$ & $9.54 \%$ & $6.80 \%$ & \\
\hline Average & $12.17 \%$ & $5.69 \%$ & $6.60 \%$ & $7.97 \%$ & $6.70 \%$ & \\
\hline 2010 & $11.39 \%$ & $8.08 \%$ & $5.66 \%$ & $8.26 \%$ & $9.81 \%$ & \multirow[t]{2}{*}{$6.00 \%$} \\
\hline 2011 & $9.59 \%$ & $8.22 \%$ & $7.13 \%$ & $8.44 \%$ & $7.38 \%$ & \\
\hline Average & $10.49 \%$ & $8.15 \%$ & $6.40 \%$ & $8.35 \%$ & $8.60 \%$ & \\
\hline
\end{tabular}

Source: Bangladesh Bank Annual Report, 2005-2011

\begin{tabular}{|c|c|c|c|c|c|c|}
\hline \multicolumn{7}{|c|}{ Table 1.2: Year-wise SLR maintenance by Islamic Banks (2005-2011) } \\
\hline \multirow[b]{2}{*}{ Year } & \multicolumn{5}{|c|}{ Actual Reserve (\%) } & \multirow{2}{*}{$\begin{array}{c}\text { Required } \\
\text { Reserve (\%) }\end{array}$} \\
\hline & $\begin{array}{c}\text { ISLAMI } \\
\text { BANK }\end{array}$ & $\begin{array}{c}\text { SHAHJA } \\
\text { BANK }\end{array}$ & $\begin{array}{c}\text { ALARA } \\
\text { BANK }\end{array}$ & $\begin{array}{c}\text { EXIM } \\
\text { BANK }\end{array}$ & SIBL & \\
\hline 2005 & $20.17 \%$ & $11.57 \%$ & $12.07 \%$ & $16.67 \%$ & $11.57 \%$ & \multirow{3}{*}{$10.00 \%$} \\
\hline 2006 & $20.63 \%$ & $10.59 \%$ & $12.01 \%$ & $12.25 \%$ & $11.14 \%$ & \\
\hline 2007 & $21.27 \%$ & $12.82 \%$ & $13.11 \%$ & $12.84 \%$ & $10.95 \%$ & \\
\hline
\end{tabular}

2 As per section 25 \& 33 of the Bank Company Act 1991, the requirement for Islamic banks' CRR is $6.00 \%$ and SLR is $11.50 \%$ (including $6.00 \%$ CRR), dated 15.12.2010. However, till the financial year 2009 , the requirement of CRR \& SLR was $5.00 \%$ and $10.00 \%$ respectively. 


\begin{tabular}{|c|c|c|c|c|c|c|}
\hline 2008 & $16.58 \%$ & $12.45 \%$ & $12.27 \%$ & $11.21 \%$ & $10.64 \%$ & \\
\hline 2009 & $19.40 \%$ & $11.02 \%$ & $14.19 \%$ & $13.26 \%$ & $11.85 \%$ & \\
\hline Average & $19.61 \%$ & $11.69 \%$ & $12.73 \%$ & $13.25 \%$ & $11.23 \%$ & \\
\hline 2010 & $17.33 \%$ & $13.98 \%$ & $11.50 \%$ & $11.50 \%$ & $14.90 \%$ & \multirow[t]{2}{*}{$11.50 \%$} \\
\hline 2011 & $15.78 \%$ & $14.50 \%$ & $12.87 \%$ & $11.70 \%$ & $13.86 \%$ & \\
\hline Average & $16.56 \%$ & $14.24 \%$ & $12.19 \%$ & $11.60 \%$ & $14.38 \%$ & \\
\hline
\end{tabular}

Source: Bangladesh Bank Annual Report, 2005-2011

From the above two tables (Table $1.1 \&$ Table 1.2) it is certain that all the banks meet their CRR and SLR requirements quite successfully from the year 2005 to 2011, except that one deficit in CRR by ALARABANK in 2010. Banks' average $^{3}$ values are telling the similar stories also. By varying CRR, the central bank can either broaden the monetary base or curtail part of the commercial banks' money creating powers. Among all, ISLAMIBANK's CRR tells the best story, except the year 2007, when EXIMBANK has the best performance. Actually, CRR is only a portion of SLR (a prescribed percentage of deposits in eligible securities), which the banks need to maintain in cash with central bank ${ }^{4}$. This is in fact, closely related to short-term liquidity requirements. Because vault cash needs are determined by customer preferences, according to their variation in payment pattern and need of the bank's customers and local businesses. However, there are all surplus results in maintenance of SLR by the banks. Here, also ISLAMIBANK is representing the best performance; for some years, far beyond the requirements.

\subsection{Analysis of Liquidity Ratios of Islamic Banks}

Liquidity ratios indicate the ability of the firm to meet recurring financial obligations. Actually, through liquidity ratios, we can measure the degree of banks' access to meet the liquidity through a quick response to immediate cash need.

\begin{tabular}{|c|c|c|c|c|c|c|}
\hline \multicolumn{7}{|c|}{ Table 1.3: Year-wise Liquidity Ratio Performance (2005-2011) } \\
\hline Ratios & Year & $\begin{array}{c}\text { ISLAMI } \\
\text { BANK }\end{array}$ & $\begin{array}{c}\text { SHAHJA } \\
\text { BANK }\end{array}$ & $\begin{array}{c}\text { ALARA } \\
\text { BANK }\end{array}$ & $\begin{array}{l}\text { EXIM } \\
\text { BANK }\end{array}$ & SIBL \\
\hline \multicolumn{7}{|c|}{ Cash and Due from Banks to Total Assets Ratio } \\
\hline & 2005 & $16.44 \%$ & $21.83 \%$ & $20.15 \%$ & $13.75 \%$ & $20.49 \%$ \\
\hline & 2006 & $16.54 \%$ & $23.24 \%$ & $13.02 \%$ & $11.34 \%$ & $15.01 \%$ \\
\hline & 2007 & $11.02 \%$ & $21.27 \%$ & $15.58 \%$ & $11.47 \%$ & $25.68 \%$ \\
\hline & 2008 & $16.01 \%$ & $20.36 \%$ & $15.46 \%$ & $12.83 \%$ & $22.63 \%$ \\
\hline & 2009 & $16.23 \%$ & $17.82 \%$ & $15.32 \%$ & $12.90 \%$ & $23.48 \%$ \\
\hline & 2010 & $13.83 \%$ & $16.11 \%$ & $17.58 \%$ & $10.14 \%$ & $21.03 \%$ \\
\hline & 2011 & $14.44 \%$ & $16.58 \%$ & $17.74 \%$ & $15.54 \%$ & $20.21 \%$ \\
\hline & Average & $14.93 \%$ & $19.60 \%$ & $16.41 \%$ & $12.57 \%$ & $21.22 \%$ \\
\hline & $\mathrm{CV}$ & $12.51 \%$ & $13.09 \%$ & $12.92 \%$ & $13.13 \%$ & $14.59 \%$ \\
\hline \multicolumn{7}{|c|}{ Cash and Due from Banks to Deposit Ratio } \\
\hline & 2005 & $18.74 \%$ & $25.84 \%$ & $26.54 \%$ & $16.37 \%$ & $24.73 \%$ \\
\hline
\end{tabular}

3 Average values have been calculated here, considering two different periods (2005-2009 \& 2010-2011), because of the differences of requirements for Islamic bank's CRR \& SLR by the Central Bank.

${ }^{4}$ Dated 01 December, 2010, as per Bangladesh Bank MPD Circular No. 04 \& 05, Islamic banks' CRR should not be less than $5.50 \%$ in any day. This requirement was $4.00 \%$ till 2009 . 


\begin{tabular}{|c|c|c|c|c|c|c|}
\hline & 2006 & $18.76 \%$ & $27.41 \%$ & $16.58 \%$ & $13.53 \%$ & $18.28 \%$ \\
\hline & 2007 & $12.68 \%$ & $26.66 \%$ & $20.44 \%$ & $14.22 \%$ & $32.08 \%$ \\
\hline & 2008 & $18.45 \%$ & $25.24 \%$ & $20.38 \%$ & $15.25 \%$ & $27.99 \%$ \\
\hline & 2009 & $18.49 \%$ & $22.12 \%$ & $19.38 \%$ & $14.55 \%$ & $29.72 \%$ \\
\hline & 2010 & $15.67 \%$ & $20.16 \%$ & $24.49 \%$ & $12.07 \%$ & $25.87 \%$ \\
\hline & 2011 & $16.44 \%$ & $21.32 \%$ & $22.28 \%$ & $18.71 \%$ & $25.52 \%$ \\
\hline & Average & $17.03 \%$ & $24.11 \%$ & $21.44 \%$ & $14.96 \%$ & $26.31 \%$ \\
\hline & CV & $12.39 \%$ & $10.97 \%$ & $14.33 \%$ & $13.19 \%$ & $15.44 \%$ \\
\hline \multicolumn{7}{|c|}{ Investment (Loans \& Advances) to Total Assets Ratio } \\
\hline & 2005 & $76.21 \%$ & $73.30 \%$ & $74.82 \%$ & $77.25 \%$ & $74.15 \%$ \\
\hline & 2006 & $75.59 \%$ & $72.70 \%$ & $81.54 \%$ & $78.10 \%$ & $77.76 \%$ \\
\hline & 2007 & $75.73 \%$ & $72.73 \%$ & $75.89 \%$ & $78.04 \%$ & $66.98 \%$ \\
\hline & 2008 & $77.99 \%$ & $72.80 \%$ & $75.91 \%$ & $78.36 \%$ & $66.93 \%$ \\
\hline & 2009 & $77.12 \%$ & $74.61 \%$ & $74.48 \%$ & $82.34 \%$ & $66.48 \%$ \\
\hline & 2010 & $79.62 \%$ & $77.97 \%$ & $71.09 \%$ & $82.51 \%$ & $66.49 \%$ \\
\hline & 2011 & $78.58 \%$ & $75.16 \%$ & $70.94 \%$ & $76.77 \%$ & $63.87 \%$ \\
\hline & Average & $77.26 \%$ & $74.18 \%$ & $74.95 \%$ & $79.05 \%$ & $68.95 \%$ \\
\hline & CV & $1.84 \%$ & $2.42 \%$ & $4.41 \%$ & $2.77 \%$ & $6.73 \%$ \\
\hline \multicolumn{7}{|c|}{ Investment (Loans \& Advances) to Deposit Ratio } \\
\hline & 2005 & $86.89 \%$ & $86.77 \%$ & $98.55 \%$ & $91.97 \%$ & $89.53 \%$ \\
\hline & 2006 & $85.77 \%$ & $85.77 \%$ & $103.86 \%$ & $93.18 \%$ & $94.70 \%$ \\
\hline & 2007 & $87.13 \%$ & $91.15 \%$ & $99.55 \%$ & $96.75 \%$ & $83.67 \%$ \\
\hline & 2008 & $89.87 \%$ & $90.23 \%$ & $100.11 \%$ & $93.14 \%$ & $82.79 \%$ \\
\hline & 2009 & $87.85 \%$ & $92.62 \%$ & $94.21 \%$ & $92.92 \%$ & $84.15 \%$ \\
\hline & 2010 & $90.17 \%$ & $97.58 \%$ & $99.06 \%$ & $98.26 \%$ & $81.78 \%$ \\
\hline & 2011 & $89.47 \%$ & $96.69 \%$ & $89.07 \%$ & $92.42 \%$ & $80.64 \%$ \\
\hline & Average & $88.16 \%$ & $91.54 \%$ & $97.77 \%$ & $94.09 \%$ & $85.32 \%$ \\
\hline & CV & $1.78 \%$ & $4.56 \%$ & $4.52 \%$ & $2.37 \%$ & $5.44 \%$ \\
\hline
\end{tabular}

Source: Calculating values using Bangladesh Bank Annual Report, 2005-2011

In the above (Table 1.3) four liquidity ratios have been calculated, considering banks' last seven years performance. Here, as per variation in percentages (CV), ISLAMIBANK is showing the best performance in almost all the cases except in their cash and due from banks to total deposits ratio, where SHAHJABANK is representing the best result. Below, we will see another liquidity determinant of Islamic bank, seven year's liquid assets ${ }^{5}$ of the banks in amount (Table 1.4), and the percentage of those liquid assets to total assets.

Table 1.4: Liquid Assets of the Banks During 2005-2011

(Amount in Million Taka)

\begin{tabular}{|c|c|c|c|c|c|}
\hline Year & $\begin{array}{c}\text { ISLAMI } \\
\text { BANK }\end{array}$ & $\begin{array}{c}\text { SHAHJA } \\
\text { BANK }\end{array}$ & $\begin{array}{c}\text { ALARA } \\
\text { BANK }\end{array}$ & $\begin{array}{c}\text { EXIM } \\
\text { BANK }\end{array}$ & SIBL \\
\hline 2005 & $23,730.70$ & $3,353.41$ & $3,090.76$ & $6,135.74$ & $4,670.83$ \\
\hline 2006 & $28,382.08$ & $5,459.00$ & $2,781.90$ & $6,738.55$ & $3,456.53$ \\
\hline
\end{tabular}

${ }^{5}$ Liquid assets are defined as cash, interbank deposits and government-issued and insured securities. 


\begin{tabular}{|c|r|r|r|r|r|}
\hline 2007 & $41,430.73$ & $6,830.57$ & $5,502.19$ & $8,158.08$ & $6,804.35$ \\
\hline 2008 & $44,461.50$ & $10,008.30$ & $7,052.26$ & $11,030.74$ & $7,495.11$ \\
\hline 2009 & $56,276.04$ & $11,600.28$ & $8,931.97$ & $12,749.03$ & $10,136.60$ \\
\hline 2010 & $57,401.96$ & $14,093.62$ & $15,249.90$ & $14,216.69$ & $12,653.80$ \\
\hline 2011 & $70,136.38$ & $19,773.97$ & $20,367.13$ & $22,950.34$ & $19,111.31$ \\
\hline Average & $45,974.20$ & $10,159.88$ & $8,996.59$ & $11,711.31$ & $9,189.79$ \\
\hline CV & 0.33 & 0.51 & 0.67 & 0.46 & 0.54 \\
\hline
\end{tabular}

Source: Calculating values using Bangladesh Bank Annual Report, 2005-2011

Highest percentage of liquid assets goes for ISLAMIBANK as per their last seven years' performance in comparison to others (Table 1.4). In fact, their coefficient of variation in maintaining those assets also reflects least fluctuation. But, the result instantly changes when we measure the proportion of liquid assets to total assets. Here, SIBL represents the best performance, if we ignore the year 2006. In 2006 SHAHJABANK experiences the best percentage of liquid assets to total assets.

\subsection{Analysis of Net Liquidity Gap of Islamic Banks}

In this section, we have analyzed the banks' last seven years net liquidity gap ${ }^{6}$ (Table 1.5).

\begin{tabular}{|c|r|r|r|r|r|}
\hline \multicolumn{7}{|c|}{ Table 1.5: Year-wise Net Liquidity Gap (NLG) During 2005- } \\
\hline Year & $\begin{array}{c}\text { ISLAMI } \\
\text { BANK }\end{array}$ & $\begin{array}{c}\text { SHAHJA } \\
\text { BANK }\end{array}$ & $\begin{array}{c}\text { ALARA } \\
\text { BANK }\end{array}$ & $\begin{array}{r}\text { EXIM } \\
\text { BANK }\end{array}$ & SIBL \\
\hline 2005 & 8,216 & 742 & 1,220 & 1,912 & 923 \\
\hline 2006 & 10,007 & 1,205 & 1,690 & 3,112 & 981 \\
\hline 2007 & 11,220 & 2,788 & 2,037 & 4,043 & 1,665 \\
\hline 2008 & 14,060 & 3,605 & 2,706 & 4,989 & 1,867 \\
\hline 2009 & 20,106 & 4,927 & 3,565 & 6,717 & 3,556 \\
\hline 2010 & 23,494 & 6,748 & 7,821 & 12,475 & 4,199 \\
\hline 2011 & 27,800 & 7,917 & 9,593 & 14,484 & 9,412 \\
\hline Average & 16,415 & 3,990 & 4,090 & 6,819 & 3,229 \\
\hline CV & 0.42 & 0.63 & 0.74 & 0.65 & 0.86 \\
\hline
\end{tabular}

Source: Calculating values using Bangladesh Bank Annual Report, 2005-2011

To overcome volatile liability, ISLAMIBANK generates most excess value in their assets among all the banks (Table 1.5). ISLAMIBANK's NLG experiences little variation in between the selected years, concerning the coefficient of variation. If we take a closer look at the individual banks' growth rate of NLG (year by year), then it is clear that there are lots of ups and downs in performance by all the banks. However, among all, perhaps the best growth rate can be found in the year of 2006-2007 by SHAHJABANK; climbing top up the line leaving all other banks behind them.

\section{Profitability Performance Analyses of Islamic BankS}

In Islam, profit is simply a reward of taking risk. So, it should be a natural outcome of the fair play of the twin forces of demand and supply in the market. Most probably, this unique feature leads them to do well even in financial crisis. But have they all been maintaining a

${ }^{6}$ The term Net Liquidity Gap (NLG), often called the net liquid assets of a firm, is the excess value of the firm's liquid assets over its volatile liabilities. 
continuous improvement in profit making performance over the last seven years? That we will see in next two sub-sections.

\subsection{Analysis of Profit Creation and Allocation from Different Sectors of the Banks}

Profit, the decisive goal of Islamic bank, is an important signal, not only to the entrepreneurs or shareholders but also to other providers of finance to a bank. Profits may generate from different sectors of the bank. Bank's return on investment is shown under (Table 2.1).

\begin{tabular}{|c|r|r|r|r|r|}
\hline \multicolumn{7}{|c|}{ Table 2.1: Profit Receipt on Investment During 2005-2011 } \\
(Amount in Million Taka) \\
\hline Year & $\begin{array}{c}\text { ISLAMI } \\
\text { BANK }\end{array}$ & $\begin{array}{c}\text { SHAHJA } \\
\text { BANK }\end{array}$ & $\begin{array}{c}\text { ALARA } \\
\text { BANK }\end{array}$ & $\begin{array}{c}\text { EXIM } \\
\text { BANK }\end{array}$ & SIBL \\
\hline 2005 & 8,336 & 1,351 & 1,118 & 2,461 & 1,678 \\
\hline 2006 & 11,158 & 2,145 & 1,701 & 3,808 & 1,899 \\
\hline 2007 & 14,572 & 2,973 & 2,243 & 4,943 & 2,093 \\
\hline 2008 & 19,544 & 4,236 & 3,502 & 6,575 & 2,732 \\
\hline 2009 & 21,371 & 5,531 & 4,005 & 8,147 & 3,079 \\
\hline 2010 & 24,766 & 6,417 & 4,244 & 9,606 & 3,886 \\
\hline 2011 & 32,020 & 10,108 & 8,975 & 13,123 & 6,922 \\
\hline Average & 18,824 & 4,680 & 3,684 & 6,952 & 3,184 \\
\hline CV & 0.40 & 0.59 & 0.66 & 0.49 & 0.53 \\
\hline
\end{tabular}

Source: Calculating values using Bangladesh Bank Annual Report, 2005-2011

ISLAMIBANK has most receipt and least variation on investment over the seven years' study period, in comparison to other banks. On the other hand, the fluctuation in profit on investment is greater for ALARABANK. Each year, a portion of each Islamic bank's profit must go for deposit amount (Table 2.2).

\begin{tabular}{|c|r|r|r|r|r|}
\hline \multicolumn{7}{|c|}{$\begin{array}{r}\text { Table 2.2: Profit Paid on Deposits During 2005-2011 } \\
\text { (Amount in Million Taka) }\end{array}$} \\
\hline Year & $\begin{array}{c}\text { ISLAMI } \\
\text { BANK }\end{array}$ & $\begin{array}{c}\text { SHAHJA } \\
\text { BANK }\end{array}$ & $\begin{array}{c}\text { ALARA } \\
\text { BANK }\end{array}$ & $\begin{array}{c}\text { EXIM } \\
\text { BANK }\end{array}$ & SIBL \\
\hline 2005 & 5,885 & 944 & 551 & 1,822 & 1,400 \\
\hline 2006 & 8,019 & 1,491 & 820 & 2,954 & 1,597 \\
\hline 2007 & 9,411 & 1,960 & 1,629 & 3,588 & 1,705 \\
\hline 2008 & 12,162 & 2,962 & 2,220 & 4,807 & 2,071 \\
\hline 2009 & 13,077 & 4,200 & 2,667 & 5,943 & 2,064 \\
\hline 2010 & 14,472 & 4,658 & 3,134 & 6,020 & 2,435 \\
\hline 2011 & 18,401 & 7,376 & 5,543 & 9,358 & 4,541 \\
\hline Average & 11,632 & 3,370 & 2,366 & 4,927 & 2,259 \\
\hline CV & 0.34 & 0.61 & 0.66 & 0.47 & 0.44 \\
\hline
\end{tabular}

Source: Calculating values using Bangladesh Bank Annual Report, 2005-2011

On an average ISLAMIBANK is subject to high payment of profit on deposits, while SIBL is just showing the reverse performance. Profit may also be generated from bank's operating activities, referred to as operating profit (Table 2.3) ${ }^{7}$.

${ }^{7}$ Operating profit is calculated by deducting the total operating expenses from total operating income. 


\begin{tabular}{|c|r|r|r|r|r|}
\hline \multicolumn{7}{|c|}{$\begin{array}{r}\text { Table 2.3: Operating Profit During 2005-2011 } \\
\text { (Amount in Million Taka) }\end{array}$} \\
\hline Year & $\begin{array}{c}\text { ISLAMI } \\
\text { BANK }\end{array}$ & $\begin{array}{c}\text { SHAHJA } \\
\text { BANK }\end{array}$ & $\begin{array}{c}\text { ALARA } \\
\text { BANK }\end{array}$ & $\begin{array}{c}\text { EXIM } \\
\text { BANK }\end{array}$ & SIBL \\
\hline 2005 & 2,869 & 502 & 548 & 1,176 & 214 \\
\hline 2006 & 3,315 & 845 & 970 & 1,379 & 296 \\
\hline 2007 & 5,162 & 1,315 & 756 & 1,908 & 481 \\
\hline 2008 & 7,952 & 1,810 & 1,528 & 2,518 & 787 \\
\hline 2009 & 7,781 & 2,041 & 1,730 & 3,182 & 1,064 \\
\hline 2010 & 9,570 & 3,529 & 3,161 & 5,894 & 1,639 \\
\hline 2011 & 12,732 & 2,998 & 3,655 & 3,956 & 2,769 \\
\hline Average & 7,054 & 1,863 & 1,764 & 2,859 & 1,036 \\
\hline CV & 0.46 & 0.55 & 0.63 & 0.54 & 0.81 \\
\hline
\end{tabular}

Source: Calculating values using Bangladesh Bank Annual Report, 2005-2011

Here, SIBL's operating profit fluctuates so much over the years, resulting in the lowest amount on an average among all. In contrast, ISLAMIBANK is indicating the best result on an average, as well as in variation over the years. However, all the earnings of a bank are subject to taxation before calculating the final net profit (Table 2.4).

\begin{tabular}{|c|r|r|r|r|r|}
\hline \multicolumn{7}{|c|}{$\begin{array}{c}\text { Table 2.4: Provision for Taxation During 2005-2011 } \\
\text { (Amount in Million Taka) }\end{array}$} \\
\hline Year & $\begin{array}{c}\text { ISLAMI } \\
\text { BANK }\end{array}$ & $\begin{array}{c}\text { SHAHJA } \\
\text { BANK }\end{array}$ & $\begin{array}{c}\text { ALARA } \\
\text { BANK }\end{array}$ & $\begin{array}{c}\text { EXIM } \\
\text { BANK }\end{array}$ & SIBL \\
\hline 2005 & 1,037 & 210 & 215 & 508 & 40 \\
\hline 2006 & 1,508 & 324 & 385 & 549 & 63 \\
\hline 2007 & 2,353 & 569 & 236 & 688 & 118 \\
\hline 2008 & 3,673 & 748 & 591 & 893 & 153 \\
\hline 2009 & 3,114 & 725 & 730 & 1,108 & 295 \\
\hline 2010 & 3,991 & 888 & 870 & 1,833 & 494 \\
\hline 2011 & 5,506 & 1,219 & 1,520 & 1,466 & 818 \\
\hline Average & 3,026 & 669 & 650 & 1,006 & 283 \\
\hline CV & 0.47 & 0.47 & 0.65 & 0.46 & 0.93 \\
\hline
\end{tabular}

Source: Calculating values using Bangladesh Bank Annual Report, 2005-2011

Tax imposed on Islamic bank is against its philosophy and poses the greatest difficulty. Profit, which is an earned income, are taxed twice, once from seller to bank and then from bank to buyer in trade financing. Here, on an average provision for taxation is highest for ISLAMIBANK and lowest for SIBL. The variation in tax provision among all is lowest for EXIMBANK. Now we will take a look at the net profit after taxation, the amount determines the banks' ultimate value to all partners related to the bank (Table 2.5).

\begin{tabular}{|c|r|r|r|r|r|}
\hline \multicolumn{7}{|c|}{ Table 2.5: Net Profit after Taxation During 2005-2011 } \\
(Amount in Million Taka) \\
\hline Year & $\begin{array}{c}\text { ISLAMI } \\
\text { BANK }\end{array}$ & $\begin{array}{c}\text { SHAHJA } \\
\text { BANK }\end{array}$ & $\begin{array}{c}\text { ALARA } \\
\text { BANK }\end{array}$ & $\begin{array}{c}\text { EXIM } \\
\text { BANK }\end{array}$ & SIBL \\
\hline 2005 & 1,126 & 256 & 263 & 555 & 14 \\
\hline
\end{tabular}




\begin{tabular}{|c|r|r|r|r|r|}
\hline 2006 & 1,401 & 463 & 470 & 650 & 58 \\
\hline 2007 & 1,427 & 647 & 347 & 931 & 150 \\
\hline 2008 & 2,675 & 818 & 668 & 1,097 & 202 \\
\hline 2009 & 3,404 & 1,071 & 859 & 1,694 & 432 \\
\hline 2010 & 4,463 & 2,072 & 1,920 & 3,476 & 643 \\
\hline 2011 & 4,841 & 1,168 & 1,772 & 2,009 & 1,083 \\
\hline Average & 2,762 & 928 & 900 & 1,487 & 369 \\
\hline CV & 0.51 & 0.60 & 0.70 & 0.64 & 0.97 \\
\hline
\end{tabular}

Source: Calculating values using Bangladesh Bank Annual Report, 2005-2011

In spite of the controversy regarding tax laws on Islamic banks' profit, all the banks have been maintaining attractive amount, if we disregard some bad performances in early years. It is clear from the above table that ISLAMIBANK generates more profit in all selected years in respect to all other banks. The fluctuation in generating net profit after tax is greater for SIBL, reflecting greater risk for partners of the bank.

\subsection{Analysis of Profitability Ratios of Islamic Banks}

Profitability ratios are the greater indicators to measure banks' access over controlling expenses and generating profit (Table 2.6).

\begin{tabular}{|c|c|c|c|c|c|c|}
\hline \multicolumn{7}{|c|}{$\begin{array}{l}\text { Table 2.6: Year-wise Profitability Ratio Performance } \\
\text { (2005-2011) }\end{array}$} \\
\hline Ratios & Year & $\begin{array}{l}\text { ISLAMI } \\
\text { BANK }\end{array}$ & $\begin{array}{l}\text { SHAHJA } \\
\text { BANK }\end{array}$ & $\begin{array}{l}\text { ALARA } \\
\text { BANK }\end{array}$ & $\begin{array}{l}\text { EXIM } \\
\text { BANK }\end{array}$ & SIBL \\
\hline \multicolumn{7}{|c|}{ Net Operating Margin (NOM) } \\
\hline \multirow[t]{9}{*}{ 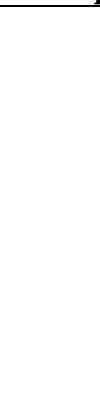 } & 2005 & $2.33 \%$ & $3.47 \%$ & $3.57 \%$ & $3.49 \%$ & $1.05 \%$ \\
\hline & 2006 & $2.21 \%$ & $3.96 \%$ & $4.54 \%$ & $3.30 \%$ & $1.50 \%$ \\
\hline & 2007 & $2.70 \%$ & $4.64 \%$ & $2.51 \%$ & $3.71 \%$ & $1.96 \%$ \\
\hline & 2008 & $3.44 \%$ & $4.00 \%$ & $3.90 \%$ & $3.68 \%$ & $2.64 \%$ \\
\hline & 2009 & $2.80 \%$ & $3.46 \%$ & $3.57 \%$ & $3.82 \%$ & $2.66 \%$ \\
\hline & 2010 & $2.89 \%$ & $4.48 \%$ & $4.19 \%$ & $5.21 \%$ & $2.97 \%$ \\
\hline & 2011 & $3.27 \%$ & $2.80 \%$ & $3.53 \%$ & $3.05 \%$ & $3.28 \%$ \\
\hline & Average & $2.81 \%$ & $3.83 \%$ & $3.69 \%$ & $3.75 \%$ & $2.29 \%$ \\
\hline & $\mathrm{CV}$ & $14.91 \%$ & $15.45 \%$ & $16.13 \%$ & $17.22 \%$ & $32.84 \%$ \\
\hline \multicolumn{7}{|c|}{ Net Profit Margin (NPM) ${ }^{9}$} \\
\hline & 2005 & $23.94 \%$ & $37.81 \%$ & $29.15 \%$ & $34.46 \%$ & $2.67 \%$ \\
\hline & 2006 & $23.27 \%$ & $43.20 \%$ & $34.74 \%$ & $32.29 \%$ & $9.12 \%$ \\
\hline & 2007 & $17.22 \%$ & $39.72 \%$ & $26.17 \%$ & $33.00 \%$ & $16.62 \%$ \\
\hline & 2008 & $22.16 \%$ & $35.20 \%$ & $30.84 \%$ & $30.90 \%$ & $15.64 \%$ \\
\hline & 2009 & $27.61 \%$ & $36.70 \%$ & $32.56 \%$ & $38.15 \%$ & $25.12 \%$ \\
\hline & 2010 & $28.51 \%$ & $42.72 \%$ & $42.77 \%$ & $45.12 \%$ & $24.42 \%$ \\
\hline & 2011 & $24.21 \%$ & $25.23 \%$ & $34.58 \%$ & $31.18 \%$ & $26.13 \%$ \\
\hline & Average & $23.85 \%$ & $37.23 \%$ & $32.97 \%$ & $35.01 \%$ & $17.10 \%$ \\
\hline
\end{tabular}

${ }^{8} \mathrm{NOM}$ is calculated by using the formula, Total Operating Profit / Total Assets.

${ }^{9}$ NPM is calculated by using the formula, Net Income after Taxes / Total Operating Income. 


\begin{tabular}{|c|c|c|c|c|c|c|}
\hline & $\mathrm{CV}$ & $14.45 \%$ & $15.08 \%$ & $14.82 \%$ & $13.46 \%$ & $48.10 \%$ \\
\hline \multicolumn{7}{|c|}{ Return on Deposits (ROD) ${ }^{10}$} \\
\hline & 2005 & $1.04 \%$ & $2.09 \%$ & $2.26 \%$ & $1.96 \%$ & $0.08 \%$ \\
\hline & 2006 & $1.06 \%$ & $2.56 \%$ & $2.80 \%$ & $1.86 \%$ & $0.36 \%$ \\
\hline & 2007 & $0.86 \%$ & $2.86 \%$ & $1.51 \%$ & $2.24 \%$ & $0.76 \%$ \\
\hline & 2008 & $1.34 \%$ & $2.24 \%$ & $2.25 \%$ & $1.90 \%$ & $0.84 \%$ \\
\hline & 2009 & $1.39 \%$ & $2.26 \%$ & $2.24 \%$ & $2.29 \%$ & $1.37 \%$ \\
\hline & 2010 & $1.53 \%$ & $3.29 \%$ & $3.55 \%$ & $3.66 \%$ & $1.43 \%$ \\
\hline & 2011 & $1.42 \%$ & $1.40 \%$ & $2.15 \%$ & $1.86 \%$ & $1.62 \%$ \\
\hline & Average & $1.23 \%$ & $2.39 \%$ & $2.39 \%$ & $2.25 \%$ & $0.92 \%$ \\
\hline & CV & $18.49 \%$ & $23.31 \%$ & $24.49 \%$ & $26.51 \%$ & $57.96 \%$ \\
\hline \multicolumn{7}{|c|}{ Return on Assets (ROA) ${ }^{11}$} \\
\hline & 2005 & $0.92 \%$ & $1.77 \%$ & $1.71 \%$ & $1.65 \%$ & $0.07 \%$ \\
\hline & 2006 & $0.93 \%$ & $2.17 \%$ & $2.20 \%$ & $1.56 \%$ & $0.29 \%$ \\
\hline & 2007 & $0.75 \%$ & $2.28 \%$ & $1.15 \%$ & $1.81 \%$ & $0.61 \%$ \\
\hline & 2008 & $1.16 \%$ & $1.81 \%$ & $1.71 \%$ & $1.60 \%$ & $0.68 \%$ \\
\hline & 2009 & $1.22 \%$ & $1.82 \%$ & $1.77 \%$ & $2.03 \%$ & $1.08 \%$ \\
\hline & 2010 & $1.35 \%$ & $2.63 \%$ & $2.55 \%$ & $3.07 \%$ & $1.17 \%$ \\
\hline & 2011 & $1.24 \%$ & $1.09 \%$ & $1.71 \%$ & $1.55 \%$ & $1.28 \%$ \\
\hline & Average & $1.08 \%$ & $1.94 \%$ & $1.83 \%$ & $1.90 \%$ & $0.74 \%$ \\
\hline & $\mathrm{CV}$ & $18.72 \%$ & $23.33 \%$ & $22.25 \%$ & $26.76 \%$ & $57.42 \%$ \\
\hline \multicolumn{7}{|c|}{ Return on Equity (ROE) ${ }^{12}$} \\
\hline & 2005 & $13.70 \%$ & $34.46 \%$ & $21.55 \%$ & $29.04 \%$ & $1.51 \%$ \\
\hline & 2006 & $14.00 \%$ & $38.44 \%$ & $27.81 \%$ & $20.90 \%$ & $5.88 \%$ \\
\hline & 2007 & $12.72 \%$ & $23.21 \%$ & $17.05 \%$ & $23.03 \%$ & $9.01 \%$ \\
\hline & 2008 & $19.02 \%$ & $22.68 \%$ & $24.70 \%$ & $21.98 \%$ & $10.82 \%$ \\
\hline & 2009 & $16.93 \%$ & $21.73 \%$ & $24.10 \%$ & $25.22 \%$ & $12.14 \%$ \\
\hline & 2010 & $19.00 \%$ & $30.71 \%$ & $24.55 \%$ & $27.86 \%$ & $15.31 \%$ \\
\hline & 2011 & $17.42 \%$ & $14.76 \%$ & $18.47 \%$ & $13.87 \%$ & $11.51 \%$ \\
\hline & Average & $16.11 \%$ & $26.57 \%$ & $22.60 \%$ & $23.13 \%$ & $9.45 \%$ \\
\hline & CV & $15.01 \%$ & $28.79 \%$ & $15.56 \%$ & $20.26 \%$ & $44.47 \%$ \\
\hline
\end{tabular}

Source: Calculating values using Bangladesh Bank Annual Report, 2005-2011

Profitability ratios indicate how much profit is produced in terms of income and capital generated from different sectors of the bank (Table 2.6). Here, on an average, NOM is higher for SHAHJABANK among all, showing highest operating profit against total assets. The smallest fluctuation (CV) exists in ISLAMIBANK's NOM. For NPM, the best performance also goes to SHAHJABANK as per their average performance over seven year's period. But during the same period, EXIMBANK's NPM is showing the lowest variation in percentage over the years. ROD can be a great concern for potential depositors. This ratio shows

${ }^{10}$ ROD is calculated by using the formula, Net Income after Taxes / Total Deposits.

${ }^{11}$ ROA is calculated by using the formula, Net Income after Taxes / Total Assets.

${ }^{12} \mathrm{ROE}$ is calculated by using the formula, Net Income after Taxes / Total Shareholders' Equity. 
percentage return of each taka of customers' deposits. Here, the depositors' choice may either SHAHJABANK or ALARABANK, having the highest percentage return on deposits among all the banks. ISLAMIBANK has least variation in ROD over the study period. Actually ROD indicates how effectively the management of a bank is able to turn deposits into net earnings. Generally, the higher the ROA, the higher should be the ROD and vice versa. That is why as the case in ROD; SHAHJABANK is also showing the best performance on an average in percentage return on assets (ROA). As expected, the slightest rise and fall over the study period reflects in ISLAMIBANK's ROA. A higher positive percentage in ROA proves greater efficiency of financial instructions by the banks' management. Like ROA, ROE is another indicator for managerial efficiency. As in earlier cases, here also SHAHJABANK carries highest average percentage return on equity (ROE), while ISLAMIBANK has little fluctuation in ROE in comparison to other banks.

\section{Liquidity and Profitability Trade-Off in Islamic BankS}

There is a trade-off between liquidity and profitability; gaining more of one ordinarily means giving up some of the other. However, in this section, we will see this relationship through multiple correlation and regression analysis between liquidity and profitability ratios (shown in Table 1.3 \& Table 2.6).

\subsection{Correlation Matrix}

The correlation coefficients are stated in Table 4.12. This gives information on the degree of correlation between all the liquidity and profitability ratios to each other.

\begin{tabular}{|c|c|c|c|c|c|c|c|c|c|}
\hline \multicolumn{10}{|c|}{ Table 3.1: Correlation Matrix of Financial Ratios used in the Analysis } \\
\hline \multicolumn{10}{|c|}{ Islami Bank Bangladesh Limited } \\
\hline & C\&D-TA & C\&D-Dep & Invst-TA & Invst-Dep & NOM & NPM & ROD & ROA & ROE \\
\hline C\&D-TA & 1 & & & 12 & & & & & \\
\hline C\&D-Dep & $.999 * *$ & 1 & & & & & & & \\
\hline Invst-TA & -.050 & -.057 & 1 & 2 & & & & & \\
\hline Invst-Dep & -.154 & -.145 & $.943^{* *}$ & 1 & & & & & \\
\hline NOM & -.166 & -.143 & .708 & $.875^{* *}$ & 1 & & & & \\
\hline NPM & .507 & .482 & .606 & 368 & .047 & 1 & & & \\
\hline ROD & .264 & .255 & $.910^{* *}$ & $.806^{*}$ & .619 & $.801^{*}$ & 1 & & \\
\hline ROA & .267 & .256 & $.909^{* *}$ & $.795^{*}$ & .593 & $.820^{*}$ & $.999 * *$ & 1 & \\
\hline ROE & .209 & .213 & $.907^{* *}$ & $.899^{* *}$ & $.772^{*}$ & .610 & $.940^{* *}$ & $.930^{* *}$ & 1 \\
\hline \multicolumn{10}{|c|}{ Shahjalal Islami Bank Limited } \\
\hline & C\&D-TA & C\&D-Dep & Invst-TA & Invst-Dep & NOM & NPM & ROD & ROA & ROE \\
\hline C\&D-TA & 1 & & & & & & & & \\
\hline C\&D-Dep & $.984^{* *}$ & 1 & & & & & & & \\
\hline Invst-TA & $-.863^{*}$ & $-.911^{* *}$ & 1 & & & & & & \\
\hline Invst-Dep & $-.958^{* *}$ & $-.907^{* *}$ & $.831^{*}$ & 1 & & & & & \\
\hline NOM & .250 & .283 & .001 & -.078 & 1 & & & & \\
\hline NPM & .433 & .362 & -.019 & -.394 & $.789^{*}$ & 1 & & & \\
\hline ROD & .070 & .052 & .275 & .041 & $.927^{* *}$ & $.878^{* *}$ & 1 & & \\
\hline ROA & .160 & .128 & .216 & -.062 & $.916^{* *}$ & $.926^{* *}$ & $.993^{* *}$ & 1 & \\
\hline ROE & .597 & .466 & -.127 & -.629 & .378 & $.805^{*}$ & .493 & .588 & 1 \\
\hline \multicolumn{10}{|c|}{ Al-Arafah Islami Bank Limited } \\
\hline & C\&D-TA & C\&D-Dep & Invst-TA & Invst-Dep & NOM & NPM & ROD & $\mathrm{ROA}$ & ROE \\
\hline C\&D-TA & 1 & & & & & & & & \\
\hline C\&D-Dep & $.974^{* *}$ & 1 & & & & & & & \\
\hline Invst-TA & -.691 & -.687 & 1 & & & & & & \\
\hline Invst-Dep & -.422 & -.273 & .740 & 1 & & & & & \\
\hline NOM & -.233 & -.168 & .253 & .324 & 1 & & & & \\
\hline NPM & .020 & .124 & -.357 & -.061 & .701 & 1 & & & \\
\hline
\end{tabular}




\begin{tabular}{|c|c|c|c|c|c|c|c|c|c|}
\hline ROD & .022 & .160 & -.124 & .255 & $.826^{*}$ & $.925^{* *}$ & 1 & & \\
\hline ROA & -.046 & .070 & -.060 & .227 & $.881^{* *}$ & $.923^{* *}$ & $.989^{* *}$ & 1 & \\
\hline ROE & -.457 & -.370 & .487 & .543 & $.890^{* *}$ & .485 & .686 & .736 & 1 \\
\hline \multicolumn{10}{|c|}{ EXIM Bank Limited } \\
\hline & C\&D-TA & C\&D-Dep & Invst-TA & Invst-Dep & $\mathrm{NOM}$ & NPM & ROD & ROA & ROE \\
\hline C\&D-TA & 1 & & & & & & & & \\
\hline C\&D-Dep & $.981^{* *}$ & 1 & & & & & & & \\
\hline Invst-TA & -.558 & -.678 & 1 & & & & & & \\
\hline Invst-Dep & $-.778^{*}$ & -.706 & .498 & 1 & & & & & \\
\hline NOM & -.717 & -.741 & $.796^{*}$ & $.805^{*}$ & 1 & & & & \\
\hline NPM & -.572 & -.637 & $.864^{*}$ & .640 & $.913^{* *}$ & 1 & & & \\
\hline ROD & -.655 & -.666 & $.768^{*}$ & $.831^{*}$ & $.969^{* *}$ & $.941^{* *}$ & 1 & & \\
\hline ROA & -.634 & -.665 & $.819^{*}$ & $.786^{*}$ & $.969^{* *}$ & $.964^{* *}$ & $.995^{* *}$ & 1 & \\
\hline ROE & -.532 & -.587 & .511 & .315 & .619 & .631 & .506 & .524 & 1 \\
\hline \multicolumn{10}{|c|}{ Social Islami Bank Limited } \\
\hline & C\&D-TA & C\&D-Dep & Invst-TA & Invst-Dep & NOM & NPM & ROD & ROA & ROE \\
\hline C\&D-TA & 1 & & & & & & & & \\
\hline C\&D-Dep & $.996^{* *}$ & 1 & & & & & & & \\
\hline Invst-TA & -.697 & -.736 & 1 & & & & & & \\
\hline Invst-Dep & -.691 & -.716 & $.984^{* *}$ & 1 & & & & & \\
\hline NOM & .278 & .335 & $-.862^{*}$ & $-.836^{*}$ & 1 & & & & \\
\hline NPM & .356 & .422 & $-.843^{*}$ & $-.781^{*}$ & $.939^{* *}$ & 1 & & & \\
\hline ROD & .300 & .363 & $-.849^{*}$ & $-.802^{*}$ & $.962^{* *}$ & $.988^{* *}$ & 1 & & \\
\hline ROA & .300 & .361 & $-.849^{*}$ & $-.806^{*}$ & $.964^{* *}$ & $.987^{* *}$ & $1.00^{* *}$ & 1 & \\
\hline ROE & .338 & .384 & $-.778^{*}$ & $-.756^{*}$ & $.916^{* *}$ & $.927^{* *}$ & $.907^{* *}$ & $.916^{* *}$ & 1 \\
\hline \multicolumn{10}{|c|}{$\begin{array}{l}\text { Pearson Correlation Coefficient } \\
* * \text { Correlation is significant at the } 0.01 \text { level (2-tailed). } \\
{ }^{*} \text { Correlation is significant at the } 0.05 \text { level (2-tailed). }\end{array}$} \\
\hline
\end{tabular}

Source: Calculating values using SPSS V15.0

The correlation matrix above shows there is a strong correlation (positive/negative, somewhere near to 1.00) among many of the liquidity and profitability variables from two different significant level, 0.01 \& 0.05 (Table 3.1). However, the matrix not only showing results of correlation between liquidity and profitability ratios but also the correlation in respect to each liquidity and profitability indicators themselves. This opportunity has been tested with the Pearson correlation coefficient test. The figures, stating the relationships are quite well defining the effect of changes in one liquidity variable to another profitability variable. The most significant correlation may be observed in ISLAMIBANK's (1\% significance level) liquidity and profitability ratios among all the selected banks.

\section{CONCLUSION}

This study dealt with multiple liquidity and profitability indicators of Islamic banks throughout the performance assessment. It also tries to focus on each bank's liquidity strength and its relationship to profitability based on correlation matrix. After overall comparison it is clear that for most cases of liquidity and profitability measurements Islami Bank Bangladesh Ltd.'s performance beats all, as they show least fluctuation in performance over the study period. However, all the Islamic banks selected for this paper, are very much alert of meeting their liquidity reserve with Central Bank as reflected in their CRR and SLR maintenance over the study period.

Depositors are always in favour of higher SLR, which not only improves the risk factor but also provides safety to the depositors' money; facilitate comfort ability when they keep deposits in an Islamic bank. While, discussing about the depositors' need, the short-term 
liquidity requirement, banks should not ignore long-term liquidity planning also. A bank's long-term liquidity planning includes forecasting funds needs over the coming year and beyond if necessary. Here, a bank's liquidity performance may be viewed to the extent to which it ensures appropriate use of funds, which illustrates bank's ability to satisfying depositors' demand while accommodating legitimate investment requests. To support their depositors' demand, banks need money, or in other sense the power to create money. That's why Akkas (1982, p.127) suggested that commercial banks should be compelled to keep reserves up to the full amount of their deposits, a reserve of 100 percent. But in doing so, they cannot ignore their potential investment opportunities.

Central bank provides a range to all commercial banks including Islamic banks, in the form of CRR and SLR, which each bank must maintain to meet both short-term and long-term liquidity crisis. Though Islamic banking and its products are totally interest free, aiming to create a noninflationary economy, the performance on average over the last 7 (seven) years for all selected Islamic banks, reflect their success in liquidity maintenance with Bangladesh (Central) Bank.

A lower profitability may arise due to the lack of control over the expenses (Maheshwari and Maheshwari, 2002, p.38). If we summarise the profitability performance in accordance with the ratios that are evaluated in this study, then the best result goes to Shahjalal Islami Bank. According to multiple regression results overall liquidity variables are found most significant with Return on Assets (ROA) of Islami Bank Bangladesh Ltd. and Return on Equity (ROE) of Shahjalal Islami Bank Ltd. among all. At the mean time none of Al-Arafah Islami Bank Ltd.'s liquidity (independent) variables is found significant to any of the two dependent (ROA/ROE) variables. At 90\% confidence level liquidity variable investment to total asset results in only statistically significant independent variable with ROA for Islami Bank Bangladesh Ltd., Shahjalal Islami Bank Ltd. and EXIM Bank Ltd., while with ROE for only Shahjalal Islami Bank Ltd. among all the liquidity variables used in the analysis.

It should be addressed that this paper marks an introductory attempt to empirically make the comparison among Islamic banks in Bangladesh. In interpreting all the results, this study uses a reduced model (liquidity and profitability with only 7 year's data). However, in any affair, current study serves as initial movement, leaving spaces for future researches to enhance and enrich its outlook.

\section{REFERENCES}

Ahmed, N., Ahmed, Z. and Naqvi, I. H., 2011, 'Liquidity Risk and Islamic Banks: Evidence from Pakistan', Interdisciplinary Journal of Research in Business, vol.1, issue.9, September, pp.99-102.

Akhtar, M. F., Ali, K. and Sadaqat, S., 2011, 'Liquidity Risk Management: A Comparative Study between Conventional and Islamic Banks of Pakistan', Interdisciplinary Journal of

Research in Business, vol.1, issue.1, January, pp.35-44.

Akhter, Dr. W., Raza, A., Orangzab and Akram, M., 2011, 'Efficiency and Performance of Islamic Banking: The Case of Pakistan', Far East Journal of Psychology and Business, vol.2, no.2, February, pp.54-70.

Akkas, Ali, 1982, 'Problem of Credit Creation by Commercial Banks in the Islamic Framework', Thoughts on Islamic Banking, $1^{\text {st }}$ Edition, February, Islamic Economics Research Bureau, Dhaka, pp.127-129.

Al-Arafah Islami Bank Ltd., 2005-2011, Annual Report 2005-2011, Al-Arafah Islami Bank Ltd., Dhaka, Bangladesh. 
Ali, S. A. and Howlader, R. A., 2005, Banking Law and Practice, $1^{\text {st }}$ Edition, November, Osman Gani of Agamee Prakashani, Bangla Bazar, Dhaka, pp.110-126, 390-419.

Faisal A. Alkassim (2005), "The Profitability of Islamic and Conventional Banking in the GCC Countries: A Comparative Study", Interdisciplinary Journal of Research in Business, vol.II, issue.1, June, pp.15-24.

Anup, A. H., 2009, 'Economic Crisis and the Overview', New Straits Times, 21 March 2012.

Athanasoglou, Panayiotis P., Delis, Matthaios D. and Staikouras, Christos K., 2008, 'Determinants of Bank Profitability in South Eastern European Region', MPRA Paper No. 10274, September 2008 viewed 92012 , $<$ http://mpra.ub.unimuenchen.de/10274/1/MPRA_paper_10274.pdf>.

Awan, A.G., 2009, 'Comparison of Islamic and Conventional Banking in Pakistan', viewed September 28, 2012, http://www.scribd.com/doc/37430208/ISlamic-Banking http://www.ciitlahore.edu.pk/pl/abrc/Proceedings/All\%20papers/COMPARISON\%20 OF\%20ISLAMIC\%20AND\%20CONVENTIONAL(Abdul\%20Ghafoor\%20Awan).pdf>.

Bashir, Abdel-Hameed M., 1999, 'Risk and Profitability Measures in Islamic Banks: The Case of two Sudanese Banks', Islamic Economic Studies, vol.6, no.2, May, pp.1-24, viewed June 2012.

Bashir, A. (2000)," Assessing the Performance of Islamic Banks: Some Evidence from The Middle East" presented at ERF Annual meeting, Amman, Jordan, October 26-26, 2000.

Bashir, A., Hassan, M. (2004),"Determinants of Islamic Banking Profitability", ERF Paper, 10th Conference.

Bordeleau, Étienne and Graham, Christopher, 2010, 'The Impact of Liquidity on Bank Profitability', Working Paper/Document de travail 2010-xx Draft, December, pp.4-22, viewed 17 July 2012.

Chowdhury, Tanbir A. and Ahmed, Kashfia, 2009, 'Performance Evaluation of Selected Private Commercial Banks in Bangladesh', International Journal of Business and Management, vol.4, no.4, April, pp.86-97, viewed 15 May 2012, $<$ http://ccsenet.org/journal/index.php/ijbm/article/download/1179/1127>.

Demerguç-Kunt, A. and Huizinga, H., 1999, 'Determinants of Commercial Bank Interest Margins and Profitability: Some International Evidence', World Bank Economic Review, vol. 13, no.2, May, pp. 379-408.

EXIM Bank Ltd., 2005-2011, Annual Report 2005-2011, EXIM Bank Ltd., Dhaka, Bangladesh. Foster, George, 2002, Financial Statement Analysis, $2^{\text {nd }}$ Edition, Pearson Education (Singapore) Pte. Ltd., Indian Branch, New Delhi, pp.57-94.

Hamid, Mohamad A. and Azmi, Shaja M., 2011, 'The Performance of Banking During 2000- 2009: Bank Islam Malaysia Berhad and Conventional Banking in Malaysia', International Journal of Economics and Management Sciences, vol.1, no.1, pp.9-19, viewed 25 June 2012.

Haron, Sudin, 2004, 'Determinants of Islamic Bank Profitability', Working Paper Series 002, March, pp.1-18, viewed 23 April 2012.

Haron, Sudin and Shanmugan, Bala, 1997, Islamic Banking System- Concepts E Applications, Pelanduk Publications, Malaysia, pp. 35-42.

Hasan, Zulfiqar and Saimoon, Ayesha, 2012, Principles of Islamic Economics, $1^{\text {st }}$ Edition, February, University Publications, Dhaka, Bangladesh, pp.47-60.

Hassoune, Anouar, 2002, 'Islamic Banks' Profitability in an Interest Rate Cycle', International Journal of Islamic Financial Service, vol.4, no.2, July-September, viewed 17 March 2012, < http://www.iiibf.org/journals/journal14/vol4no2art2.pdf >. 
Ika, Siti Rochmah and Abdullah, Norhayati, 2011, 'A Comparative Study of Financial Performance of Islamic Banks and Conventional Banks in Indonesia', International Journal of Business and Social Science, vol.2, no.15, August, pp.199-207, viewed 5 May 2012, $<$ http://www.ijbssnet.com/journals/Vol 2 No 15 August 2011/22.pdf $>$.

Islam, M. Muzahidul, 2008, 'Liquidity Management', Text Book on Islamic Banking, $2^{\text {nd }}$ Edition, November, Islamic Economics Research Bureau, Dhaka, Bangladesh, pp.101- 111.

Islam, M. Muzahidul and Chowdhury, Hasibul Alam, 2009, 'A Comparative Study of Liquidity Management of an Islamic Bank and a Conventional Bank: The Evidence from Bangladesh', Journal of Islamic Economics, Banking and Finance, vol.5, no.1, January-April, pp.89-108.

Islami Bank Bangladesh Ltd., 2005-2011, Annual Report 2005-2011, Islami Bank Bangladesh Ltd., Dhaka, Bangladesh.

Khan, Dr. Tariqullah and Ahmed, Dr. Habib, 2001,'Risk Management: An Analysis of Issues in Islamic Financial Industry', Occasional Paper, no.5, pp.38-39, viewed 7 July 2012.

Khrawish, H. A., Siam, W. Z. and Khrawish, A. H., 2011, 'Determinants of Islamic Bank Profitability: Evidence from Jordan', Middle Eastern Finance and Economics, issue.13, May, pp. 43-57.

Kuppusamy, M., Saleh, Ali S. and Samudhram, Ananda, 2010, 'Measurement of Islamic Banks Performance using a Shariah Conformity and Profitability Model', Review of Islamic Economics, vol.13, no.2, pp.35-48, viewed 21 May 2012, <http://www.islamicfoundation.org.uk/JournalsPDF/IslamicEconomicsReviewAd.pdf>

Latif, Muhammad Abdul, 1982, 'Is Indexation of Loan Permitted?', Thought on Islamic Banking, $1^{\text {st }}$ Edition, February, Islamic Economics Research Bureau, Dhaka, Bangladesh, pp.112-113.

Lau, M. S., 2008, 'The Recent Crisis: Economic Review', New Straits Times, $3^{\text {rd }}$ April 2012.

Levin, Richard I. and Rubin, David S., 2003, Statistics for Management, $7^{\text {th }}$ Edition, Prentice Hall of India Private Limited, New Delhi, India, pp.717-790.

Lewis M. And Algaoud L. (2001), "Islamic Banking”, Edward Elgar Publishing Limited.

Lind, Douglas A., Marchal, Willian G. and Warthen, Samuel A., 2005, Statistical Techniques in Business $\mathcal{E}$ Economics, $12^{\text {th }}$ Edition, McGraw-Hill Companies, U.S.A, pp.474-521.

Maheshwari, Dr. S. N. and Maheshwari, Dr. S. K., 2002, Banking, $11^{\text {th }}$ Edition, Kalyani Publishers, New Delhi, Section VII, pp.37-84.

Mahmud, Abdullah Al and Islam, M. Muzahidul, 2008, 'A Comparative Study on Performance Evaluation of Conventional Banks and Islamic Banks in Bangladesh with Special Reference to Islamic Bank Bangladesh Ltd.', Journal of Thoughts on Economics, vol.18, no.5, October-December, pp.25-43.

Maali, B. Casson, P. and Napier C. (2006)," Social Reporting by Islamic Banks", Accounting Foundation, The University of Sydney.

Naceur, Samy Ben and Goaied, Mohamed, 2008, 'The Determinants of Commercial Bank Interest Margin and Profitability: Evidence from Tunisia', Frontiers in Finance and Economics, vol.5, issue.1, pp. 106-130.

Raquib, A., 2006, Emergence of Islamic Banking in Bangladesh and Related Financial Issues, $1^{\text {st }}$ Edition, February, Sabdarup Publications, Dhaka, Bangladesh, pp.1-62.

Rashid, Hafiz A. and Ashraf, Mian M., 2011, 'Achievement Anecdote of Islamic Banking Practices in Pakistan: A Review of Past, Present and Future Performance with Pragmatic and Analytical Approach', Journal of Money, Investment and Banking, issue.22, Eurojournals Publishing Inc., pp.70-86, viewed 13 July 2012. 
Rashid, Mamunur and Nishat, Ainun, 2009, 'Disparity of Performance Indicators of Islamic Banks: Study on Bangladesh', International Journal of Business and Management, vol.4, no.8, August, pp.52-72, viewed 9 May 2012.

Rose, Peter S., 2004-2005, Commercial Bank Management, Irwin/McGraw-Hill, U.S.A, pp.149-198.

Rosly, Saiful A. and Bakar, Mohd. A. A., 2003, 'Performance of Islamic and Mainstream Banks in Malaysia', International Journal of Social Economics, vol.30, no.12, pp.1249-1265, viewed 1 June 2012.

Rosly, Saiful A. and Zaini, Mohammad Ashadi Mohd., 2008, 'Risk-return analysis of Islamic banks' investment deposits and shareholders' fund', Managerial Finance, vol.34, no.10, pp.695707, viewed 11 July 2012, <http://www.kantakji.com/fiqh/files/banks/c1017.pdf >.

Sadeq, Dr. Abul H. M., 2006, Readings in Islamic Economic Thought, $1^{\text {st }}$ Edition, October, Islamic Foundation Bangladesh, Agargaon, Dhaka, pp.17-18.

Safiullah, Md., 2010, 'Superiority of Conventional Banks $\mathcal{E}$ Islamic Banks of Bangladesh: A Comparative Study', International Journal of Economics and Finance, vol.2, no.3, August, pp.199-207, viewed 29 April 2012.

Saleem, Qasim and Rehman, Ramiz Ur, 2011, 'Impacts of Liquidity Ratios on Profitability (Case of Oil and Gas Companies of Pakistan)', Interdisciplinary Journal of Research in Business, vol.1, issue.7, July, pp.95-98, viewed 3 August 2012, $<$ http://www.idjrb.com/articlepdf/idjrb7n9.pdf $>$.

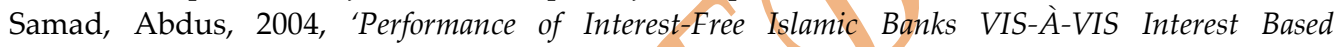
Conventional Banks of Bahrain', IIUM Journal of Economics and Management, vol.12, no.2, pp.1-15, viewed 21 May 2012, <http://iium.edu.my/enmjournal/122art1.pdf >.

Samad, Abdus and Hasan, M. Kabir, 1999, 'The Performance of Malaysian Islamic Bank During 1984-1997: An Explanatory Study', International Journal of Islamic Financial Services, vol.1, no.3, October-December, viewed 13 June 2012.

Siddiqui, S. A., 2010, 'Establishing the Need and Suggesting a Strategy to Develop Profit and Loss Sharing Islamic Banking', Journal of Islamic Economics- Banking and Finance, vol.6, no.4, October-December, pp.29-52.

Shahchera, Mahshid, 2012, 'The Impact of Liquidity Asset on Iranian Bank Profitability', International Conference on Management, Behavioral Sciences and Economics Issues (ICMBSE'2012), Penang, Malaysia, pp. 131-135.

Shahjalal Islami Bank Ltd., 2005-2011, Annual Report 2005-2011, Shahjalal Islami Bank Ltd., Dhaka, Bangladesh.

Social Islami Bank Ltd., 2005-2011, Annual Report 2005-2011, Social Islami Bank Ltd., Dhaka, Bangladesh.

Toni, Uhomoibhi, 2008, 'Determinants of Bank Profitability: Macroeconomic Evidence from Nigeria', Deakin university, (working paper).

Usmani, Muhammad Taqi, 1993, An Introduction to Islamic Finance, March, IDATARUL 